\title{
Article \\ Soil Lead (Pb) in New Orleans: A Spatiotemporal and Racial Analysis
}

\author{
Sara Perl Egendorf ${ }^{1, *,+} \mathbb{D}$, Howard W. Mielke ${ }^{2, *,+} \mathbb{D}$, Jorge A. Castorena-Gonzalez ${ }^{2} \mathbb{D}$, Eric T. Powell $^{3}$ \\ and Christopher R. Gonzales $2,3,+$
}

1 Cornell Atkinson Center for Sustainability and School of Integrative Plant Science, Cornell University College of Agriculture and Life Sciences, Ithaca, NY 14853, USA

2 Department of Pharmacology, Tulane School of Medicine, New Orleans, LA 70112, USA; jcastorenagonzalez@tulane.edu (J.A.C.-G.); chrisgc99@gmail.com (C.R.G.)

3 Lead Lab, Inc., New Orleans, LA 70119-3231, USA; powellet2@gmail.com

* Correspondence: spe34@cornell.edu (S.P.E.); hmielke@tulane.edu (H.W.M.)

+ These authors contributed equally to this work.

Citation: Egendorf, S.P.; Mielke, H.W.; Castorena-Gonzalez, J.A.; Powell, E.T.; Gonzales, C.R. Soil Lead $(\mathrm{Pb})$ in New Orleans: A Spatiotemporal and Racial Analysis. Int. J. Environ Res. Public Health 2021, 18, 1314. https://doi.org/10.3390/ ijerph18031314

Academic Editor: Vikas Kumar

Received: 17 December 2020

Accepted: 28 January 2021

Published: 1 February 2021

Publisher's Note: MDPI stays neutral with regard to jurisdictional claims in published maps and institutional affiliations.

Copyright: (c) 2021 by the authors. Licensee MDPI, Basel, Switzerland. This article is an open access article distributed under the terms and conditions of the Creative Commons Attribution (CC BY) license (https:// creativecommons.org/licenses/by/ $4.0 /)$.

\begin{abstract}
Spatialized racial injustices drive morbidity and mortality inequalities. While many factors contribute to environmental injustices, $\mathrm{Pb}$ is particularly insidious, and is associated with cardiovascular, kidney, and immune dysfunctions and is a leading cause of premature death worldwide. Here, we present a revised analysis from the New Orleans dataset of soil lead ( $\mathrm{SPb}$ ) and children's blood $\mathrm{Pb}(\mathrm{BPb})$, which was systematically assembled for 2000-2005 and 2011-2016. We show the spatial-temporal inequities in $\mathrm{SPb}$, children's $\mathrm{BPb}$, racial composition, and household income in New Orleans. Comparing medians for the inner city with outlying areas, soil $\mathrm{Pb}$ is 7.5 or 9.3 times greater, children's blood $\mathrm{Pb}$ is $\sim 2$ times higher, and household income is lower. Between 20002005 and 2011-2016, a BPb decline occurred. Long-standing environmental and socioeconomic $\mathrm{Pb}$ exposure injustices have positioned Black populations at extreme risk of adverse health consequences. Given the overlapping health outcomes of $\mathrm{Pb}$ exposure with co-morbidities for conditions such as COVID-19, we suggest that further investigation be conducted on $\mathrm{Pb}$ exposure and pandemicrelated mortality rates, particularly among Black populations. Mapping and remediating invisible environmental $\mathrm{Pb}$ provides a path forward for preventing future populations from developing a myriad of $\mathrm{Pb}$-related health issues.
\end{abstract}

Keywords: community disparities; environmental justice; lead exposure; blood $\mathrm{Pb}$; comorbidity

\section{Introduction}

Lead $(\mathrm{Pb})$ exposure is responsible for more than one million deaths worldwide each year, and 24.4 million disability-adjusted life years [1]. According to a population-based cohort study by Lanphear et al. (2018), Pb is responsible for approximately 412,000 deaths in the US per year [2], which is "comparable to tobacco smoke as a leading cause of mortality" [3]. However, this exposure is often mediated by social factors, particularly race [4]. The disproportionate exposure and environmental injustice of Black and lowincome communities to environmental $\mathrm{Pb}$ has long been recognized [5-7].

Exposure to $\mathrm{Pb}$ adversely impacts all bodily systems and is particularly associated with organ impairments to the heart, kidney, and nervous systems [8]. Pb is widely distributed throughout the body and the mechanisms of toxicity are common to all cell types, impacting organ systems over a wide range of blood $\mathrm{Pb}(\mathrm{BPb})(\leq 5->50 \mu \mathrm{g} / \mathrm{dL})$. Prior to the 1960s, the blood $\mathrm{Pb}$ guideline for acceptable exposure was $60 \mu \mathrm{g} / \mathrm{dL}$. The guidelines of "acceptable" exposure decreased numerous times as analytical measurements improved and clinical studies indicated that adverse health effects appeared at lower levels of $\mathrm{Pb}$ exposure [9]. By 2012, researchers realized that "there is no known safe level of lead exposure" [10]. 
Tremendous advances have been made in reducing exposure to $\mathrm{Pb}$, particularly by banning leaded gasoline, paint, and solder over the past few decades. However, the legacies of leaded gasoline, peeling paint, waste incineration and industrial activities are stored in environmental reservoirs, particularly in soil. Soil studies conducted in urban environments indicate that some communities, based on city size and location within the city, are disproportionately $\mathrm{Pb}$ contaminated. Urban studies found similar soil $\mathrm{Pb}$ patterns in Baltimore, cities in Minnesota, Louisiana, and UK cities [11-13]. The racial associations and environmental injustices of SPb have also been shown in Santa Ana, California, where census tracts with median household income $<$ USD 50,000 had five times higher soil $\mathrm{Pb}$ concentrations than high-income census tracts [14]. Reducing the amount of $\mathrm{Pb}$ in the environments of communities also reduces blood $\mathrm{Pb}$ [15].

This study investigates temporal and spatial changes in environmental lead $(\mathrm{Pb})$, children's $\mathrm{Pb}$ exposure, and the ways in which this exposure are associated with social formations such as racial categories and socioeconomic status across the entire city of New Orleans. The data for this study were analyzed from a unique database compiled to measure the concurrent declines of soil $\mathrm{Pb}(\mathrm{SPb})$ and children's blood $\mathrm{Pb}(\mathrm{BPb})$ over an interval of $\sim 15$ years in New Orleans [15]. Here we analyze the SPb and $\mathrm{BPb}$ data by several variables, including distance from the city center, residential racial population, and household income over two time periods. We hypothesize that Black communities in New Orleans are disproportionately exposed to environmental $\mathrm{Pb}$ in soil, causing increased $\mathrm{BPb}$ burdens. As we will discuss, the impacts of $\mathrm{Pb}$ exposure strongly overlap with immune dysfunctions, and many of the pre-existing health conditions that increase the severity of COVID-19, highlighting the need for further study of this topic. Our aim is to recognize specific and compounding environmental injustices in the midst of the global coronavirus pandemic -issues that can be remedied, particularly for the most vulnerable populations.

\section{Methods}

\subsection{Soil Lead Data}

In New Orleans, two soil Pb surveys were conducted that collected soil samples by census tracts (in 1998-2001 and 2013-2017). The two surveys were collected by the same personnel using the same extraction preparation methods and equipment and the same Spectro Inductively Coupled Plasma (ICP) analytical instrument [15]. The samples were collected in the same census tract locations using the 1990 boundaries [16]. The protocol was implemented consistently in both surveys and required the collection of nineteen surficial (2-3 cm depth) soil samples, as explained in detail in the following references $[15,17]$. After analysis, the median $\mathrm{SPb}$ results for each census tract were calculated. The datasets generated and analyzed for the current study are available in the Supplementary Materials Section (Table S2).

\subsection{Children's Blood Pb Data}

Children's blood $\mathrm{Pb}$ data were provided by the Louisiana Healthy Homes and Childhood Lead Poisoning Prevention Program (LHHCLPPP). There may have been a change in the sensitivity of the instruments used in the 2000-2005 BPb survey compared with the 2011-2016 BPb survey. The outcome was that the apparent lowest level of detection found in 2000-2005 was $3 \mu \mathrm{g} / \mathrm{dL}$, while the lowest level of detection found in 2011-2016 was $1 \mu \mathrm{g} / \mathrm{dL}$ (see Figures 1 and 2). Children's BPb data for both New Orleans and the United States decreased during this time. Census tracts were included only if there were 5 or more $\mathrm{BPb}$ datapoints. The census tracts that included both $\mathrm{SPb}$ and $\mathrm{BPb}(n=274)$ were matched. The BPb dataset collected by LHHCLPPP between 2000 and 2005 consists of 54,695 independent $\mathrm{BPb}$ results. The second LHHCLPPP BPb dataset was collected from 2011 to 2016 and consists of $27,249 \mathrm{BPb}$ results from the same 274 census tracts [15]. 


\subsection{Interpolated Soil $\mathrm{Pb}$ and Blood $\mathrm{Pb}$ Data}

The median $\mathrm{SPb}$ or $\mathrm{BPb}$ levels were assigned to the center of mass of the corresponding 1990 census tracts [18]. Using these point values, continuous raster surfaces for the study area were created for $\mathrm{SPb}$ or $\mathrm{BPb}$ by Ordinary Point Kriging interpolation using Surfer 17 [19]. The surfaces had the following dimensions: 1821 columns and 1176 rows, with a cell size of $20 \times 20 \mathrm{~m}^{2}$. The geodetic datum used was the North American Datum 1983 (NAD83), and the map projection was Universal Transverse Mercator, Zone 15 North (UTM 15N). The resulting surfaces were saved in Environmental Systems Research Institute (ESRI)Grid format. The interpolated values of $\mathrm{SPb}$ or $\mathrm{BPb}$ were extracted from corresponding Grids and joined to the corresponding center of mass of 2000 or 2010 US Census polygons. This was done using the Extract Values to Points Spatial Analyst Tool in ArcGIS 10.2 [20].

\subsection{Spatial-Temporal Analysis}

The New Orleans Main Post Office (MPO), 701 Loyola Ave, New Orleans, LA 70113, was selected as the central location of the city. Precedence for choosing the Main Post Office as the central location was established in a Baltimore urban garden study [11], particularly since the postal service was designed to maximize mail delivery efficiency in each city [21]. Distance analysis was conducted using the center of mass of census tracts as the distance from the MPO, estimated by the ArcGIS Point Distance Analysis tool [18]. The census tracts were divided according to distance by deciles. The raster cell values were appended to the tabular data associated with the census tract center of mass shape files. The census tract data on racial composition and socioeconomic data for the two surveys are from Integrated Public Use Microdata Series (IPUMS) [22].

\subsection{Statistical Analyses}

Statistical analyses were conducted using data-dependent permutation procedure models, such that outliers were not removed, nor were transformations of the dataset conducted [23,24]. The Multi-Response Permutation Procedure (MRPP) was used to calculate the exact moments of the underlying permutation distribution of all possible arrangements of the observed data (Table 1). This procedure produces statistical comparisons with distance function-based permutation tests and calculates statistical significance between treatments [25]. To measure the clinical, practical, or substantive significance of these statistical tests, we used the chance-corrected measure of effect size that is appropriate for MRPP, Mielke's R. This measure of effect size provides a percentage of within-group agreement above what would be expected by chance [26]. Kendall's tau-b rank correlation evaluates the strength of the associations between the variables. In this study, Kendall's tau-b was calculated to evaluate pairs of observations to determine the overall strength of association based on the concordance and discordance of the ranked pairs (see Table S1 in the Supplementary Materials) [27].

\section{Results}

\section{Environmental Signaling Over Time and Distance}

Table 1 shows the census tract results divided into NEAR census tracts and FAR census tracts according to their distance from the Main Post Office (MPO). Table 1 lists the population density, percent racial composition, environmental $\mathrm{Pb}$, children's blood $\mathrm{Pb}$, and household income characteristics. The differences between each of these characteristics for NEAR and FAR groups were analyzed with Multi-Response Permutation Procedure (MRPP) statistics [23]. The medians for soil $\mathrm{Pb}$, children's blood $\mathrm{Pb}$, racial composition, and household income show that compared with FAR communities, NEAR communities have 9.3 or 7.5 times higher median SPb ( $p$-values $<10^{-34}$ ), with a substantive Mielke's $\mathrm{R}$ effect size of $35 \%$ in the 2000 survey and 30\% in the 2015 survey. Children tested have higher median $\mathrm{BPb}$ concentrations by a factor of $\sim 2\left(p\right.$-values $\left.<10^{-35}\right)$, with an $\mathrm{R}$ effect size of $41 \%$ in 2000 and $34 \%$ in 2015. Annual median household income is lower by USD 16,000 or $\sim$ USD 13,000 ( $p$-values $<10^{-6}$ ), with an R effect size of $15 \%$ in 2000 and $4 \%$ in 
2015. With increasing distance from the city center, the percentage of White residents increases, and the percentage of Black residents decreases ( $p$-values $<10^{-5}$ ), with R effect sizes of $\sim 13 \%$ in 2000 and $\sim 4 \%$ in 2015. As indicated by these results, White populations and income increase as $\mathrm{SPb}$ and $\mathrm{BPb}$ decrease with distance from the city center.

Comparing the two temporal surveys, children's median BPb levels in NEAR and FAR communities between 2000-2005 and 2011-2016 exhibit the following Mielke's R effect size and $p$-values, respectively (not shown in Table 2): all survey results for the two time periods- $37 \%$ and $4.3 \times 10^{-92}$; for NEAR vs. NEAR results- $46 \%$ and $3.5 \times 10^{-51}$; and for FAR vs. FAR results- $76 \%$ and $1.3 \times 10^{-61}$. We assume that the $\mathrm{BPb}$ results are representative of the total populations living in the NEAR and FAR groups of Metropolitan New Orleans. There were profound reductions in children's BPb between 2000-2005 and 2011-2016 in NEAR and FAR groups.

Table 1. The percentage of White, Black, and Other populations, median interpolated soil $\mathrm{Pb}$, median interpolated blood $\mathrm{Pb}$, and median household incomes in 2000 and 2015 for NEAR and FAR groups from the main post office. The median household income data are from IPUMS [22].

\begin{tabular}{|c|c|c|c|c|c|c|c|c|c|}
\hline & $\begin{array}{c}\text { Dist. MPO } \\
\text { km }\end{array}$ & Area $\mathrm{km}^{2}$ & Pop.km² & $\begin{array}{c}\% \\
\text { White }\end{array}$ & $\begin{array}{c}\% \\
\text { Black }\end{array}$ & $\begin{array}{c}\% \\
\text { Other }\end{array}$ & $\begin{array}{c}\mathrm{SPb} \\
\mathrm{mg} / \mathrm{kg}\end{array}$ & $\begin{array}{c}\mathrm{BPb} \\
\mu \mathrm{g} / \mathrm{dL}\end{array}$ & $\begin{array}{l}\text { Household } \\
\text { Income US\$ }\end{array}$ \\
\hline \multicolumn{10}{|l|}{2000} \\
\hline \multicolumn{10}{|l|}{ NEAR } \\
\hline $\mathrm{N}$ of Census Tracts & 147 & 147 & 147 & 147 & 147 & 147 & 147 & 147 & 147 \\
\hline Minimum & 0.0 & 0.1 & 294 & 0.0 & 0.9 & 0.3 & 35 & 3.0 & 4621 \\
\hline $50 \%$ & 3.8 & 0.6 & 3892 & 23.0 & 72.7 & 3.1 & 410 & 5.7 & 21,981 \\
\hline Maximum & 6.2 & 6.4 & 15,527 & 97.4 & 99.5 & 24.8 & 1774 & 10.6 & 109,721 \\
\hline \multicolumn{10}{|l|}{ FAR } \\
\hline $\mathrm{N}$ of Census Tracts & 147 & 147 & 147 & 147 & 147 & 147 & 147 & 147 & 146 \\
\hline Minimum & 6.2 & 0.5 & 22 & 0.0 & 0.0 & 0.0 & 6 & 2.1 & 16,250 \\
\hline $50 \%$ & 10.2 & 1.6 & 2388 & 78.1 & 12.7 & 4.2 & 44 & 3.0 & 37,919 \\
\hline Maximum & 20.9 & 18.8 & 6476 & 98.7 & 100.0 & 21.5 & 237 & 5.0 & 146,158 \\
\hline$p$-Value & $2.5 \times 10^{-53}$ & $\begin{array}{c}1.7 \times \\
10^{-26}\end{array}$ & $\begin{array}{c}1.4 \times \\
10^{-19}\end{array}$ & $\begin{array}{c}5.2 \times \\
10^{-14}\end{array}$ & $\begin{array}{c}1.8 \times \\
10^{-14}\end{array}$ & $\begin{array}{r}4.3 \times \\
10^{-5}\end{array}$ & $\begin{array}{c}4.8 \times \\
10^{-40}\end{array}$ & $\begin{array}{c}2.1 \times \\
10^{-42}\end{array}$ & $2.4 \times 10^{-22}$ \\
\hline Mielke's R & 0.425 & 0.143 & 0.127 & 0.130 & 0.138 & 0.028 & 0.349 & 0.411 & 0.149 \\
\hline \multicolumn{10}{|l|}{2015} \\
\hline $\mathrm{N}$ of Census Tracts & 143 & 143 & 143 & 143 & 143 & 143 & 143 & 143 & 141 \\
\hline Minimum & 0.4 & 0.16 & 307 & 0.0 & 0.4 & 0.0 & 16 & 1.0 & 8738 \\
\hline $50 \%$ & 3.9 & 0.64 & 2813 & 40.8 & 51.5 & 4.4 & 187 & 2.1 & 30,917 \\
\hline Maximum & 6.7 & 5.05 & 7702 & 97.0 & 100.0 & 21.1 & 910 & 4.9 & 155,714 \\
\hline \multicolumn{10}{|l|}{ FAR } \\
\hline N of Census Tracts & 143 & 143 & 143 & 143 & 143 & 143 & 143 & 143 & 143 \\
\hline Minimum & 6.7 & 0.46 & 98 & 0.0 & 0.0 & 0.0 & 6 & 0.5 & 18,114 \\
\hline $50 \%$ & 10.6 & 1.44 & 2170 & 71.5 & 17.0 & 5.5 & 25 & 1.0 & 44,357 \\
\hline Maximum & 20.9 & 18.65 & 6900 & 99.4 & 100.0 & 24.9 & 127 & 3.3 & 161,250 \\
\hline$p$-Value & $4.2 \times 10^{-53}$ & $\begin{array}{l}8.7 \times \\
10^{-22}\end{array}$ & $\begin{array}{r}1.2 \times \\
10^{-9}\end{array}$ & $\begin{array}{r}5.8 \times \\
10^{-5}\end{array}$ & $\begin{array}{r}2.0 \times \\
10^{-5}\end{array}$ & 0.016 & $\begin{array}{l}1.4 \times \\
10^{-34}\end{array}$ & $\begin{array}{c}2.6 \times \\
10^{-35}\end{array}$ & $5.1 \times 10^{-6}$ \\
\hline Mielke's R & 0.437 & 0.115 & 0.062 & 0.036 & 0.042 & 0.010 & 0.301 & 0.335 & 0.035 \\
\hline
\end{tabular}

Table 2 shows the New Orleans census tract sector characteristics as a function of distance sectors during two time periods. The spaciotemporal characteristics of race, $\mathrm{SPb}$, $\mathrm{BPb}$, and household income, along with other characteristics, are given. The top panel of Table 2 shows that, in 2000-2005, majority Black communities predominantly inhabited distance sectors 1-5, where the median $\mathrm{SPb}$ was $505 \mathrm{mg} / \mathrm{kg}$. Majority White communities, distance sectors 6-10, inhabited communities where the median $\mathrm{SPb}$ for the sectors was $47 \mathrm{mg} / \mathrm{kg}$. The bottom panel shows the characteristics of the distance sectors in 20112015. Especially noteworthy is the downward shift in both $\mathrm{SPb}$ and $\mathrm{BPb}$. In sectors 1-5, the median $\mathrm{SPb}$ declined to $215 \mathrm{mg} / \mathrm{kg}$ (from $505 \mathrm{mg} / \mathrm{kg}$ ) and in sectors 6-10 the $\mathrm{SPb}$ 
declined to $32 \mathrm{mg} / \mathrm{kg}$ (from $47 \mathrm{mg} / \mathrm{kg}$ ). Black people were still more likely to inhabit high- $\mathrm{Pb}$ areas, but some changes are noted with black residents living in higher proportions in outlying sectors. Especially noteworthy is the decrease in children's BPb. In 2011-2015, children's median BPb in distance sectors 1-5 was $2.2 \mu \mathrm{g} / \mathrm{dL}$ (down from $5.7 \mu \mathrm{g} / \mathrm{dL}$ in 2000-2005). The decline in $\mathrm{BPb}$ was concurrent with the decrease in $\mathrm{SPb}$, as described previously [15].

Table 2. New Orleans Census tract characteristics, soil $\mathrm{Pb}(\mathrm{SPb})$, and children's blood $\mathrm{Pb}(\mathrm{BPb})$ are divided into 10 distance sectors from the Main Post Office (PO). The population density is inhabitants per square kilometer. The interpolated values for $\mathrm{SPb}, \mathrm{BPb}$, and household income are also given.

\begin{tabular}{|c|c|c|c|c|c|c|c|c|c|c|}
\hline \multicolumn{11}{|c|}{ SECTOR MEDIANS } \\
\hline 2000-2005 & $\mathbf{N}$ & $\begin{array}{l}\text { Main } \\
\text { PO }\end{array}$ & $\begin{array}{c}\text { Main } \\
\text { PO }\end{array}$ & Pop. & & & & $\mathrm{SPb}$ & $\mathrm{BPb}$ & Household \\
\hline Sector & CTs & $\begin{array}{r}\text { MIN } \\
\text { DIST } \\
\text { km }\end{array}$ & $\begin{array}{r}\text { MAX } \\
\text { DIST } \\
\text { km }\end{array}$ & Density & $\%$ White & $\%$ Black & $\%$ Other & $\begin{array}{r}\text { Soil Pb } \\
\text { (interp.) }\end{array}$ & $\begin{array}{r}\text { Blood Pb } \\
\text { (interp.) }\end{array}$ & $\begin{array}{r}\text { Income } \\
\text { US\$ }\end{array}$ \\
\hline 1 & 30 & 0.00 & 2.32 & 4506 & 21.90 & 74.80 & 3.08 & 615 & 6.8 & 11,950 \\
\hline 2 & 29 & 2.36 & 3.25 & 5122 & 14.77 & 82.11 & 3.27 & 541 & 6.3 & 21,619 \\
\hline 3 & 29 & 3.27 & 4.22 & 4129 & 22.99 & 74.37 & 2.81 & 505 & 5.7 & 21,456 \\
\hline 4 & 30 & 4.30 & 5.31 & 3786 & 27.31 & 70.46 & 2.73 & 275 & 5.0 & 23,608 \\
\hline 5 & 29 & 5.31 & 6.16 & 2589 & 22.85 & 72.60 & 3.37 & 133 & 4.0 & 27,526 \\
\hline 6 & 29 & 6.19 & 7.45 & 2344 & 64.97 & 26.29 & 3.62 & 69 & 3.0 & 33,839 \\
\hline 7 & 30 & 7.57 & 8.93 & 2377 & 77.75 & 15.04 & 4.13 & 55 & 3.0 & 40,014 \\
\hline 8 & 29 & 8.97 & 11.60 & 2388 & 87.36 & 5.11 & 4.16 & 47 & 3.0 & 34,250 \\
\hline 9 & 29 & 11.81 & 14.97 & 2577 & 91.18 & 1.38 & 3.03 & 44 & 3.0 & 40,086 \\
\hline 10 & 30 & 14.97 & 20.92 & 1990 & 74.79 & 15.92 & 6.03 & 22 & 3.0 & 39,699 \\
\hline TOTAL & 294 & & & & & & & & & \\
\hline \multicolumn{11}{|c|}{ SECTOR MEDIANS } \\
\hline 2011-2015 & $\mathbf{N}$ & $\begin{array}{l}\text { Main } \\
\text { PO }\end{array}$ & $\begin{array}{l}\text { Main } \\
\text { PO }\end{array}$ & Pop. & & & & $\mathrm{SPb}$ & $\mathrm{BPb}$ & Household \\
\hline Sector & CTs & $\begin{array}{r}\text { MIN } \\
\text { DIST } \\
\text { km }\end{array}$ & $\begin{array}{r}\text { MAX } \\
\text { DIST } \\
\text { km }\end{array}$ & Density & $\%$ White & $\%$ Black & $\%$ Other & $\begin{array}{r}\text { Soil Pb } \\
\text { (interp.) }\end{array}$ & $\begin{array}{r}\text { Blood Pb } \\
\text { (interp.) }\end{array}$ & $\begin{array}{r}\text { Income } \\
\text { US\$ }\end{array}$ \\
\hline 1 & 29 & 0.38 & 2.49 & 3610 & 29.17 & 64.74 & 4.78 & 282 & 2.4 & 25,389 \\
\hline 2 & 28 & 2.50 & 3.36 & 3632 & 31.16 & 61.83 & 4.67 & 254 & 2.5 & 28,927 \\
\hline 3 & 29 & 3.38 & 4.38 & 2707 & 48.33 & 43.29 & 4.37 & 215 & 2.2 & 34,583 \\
\hline 4 & 28 & 4.38 & 5.41 & 2582 & 46.18 & 45.07 & 4.30 & 135 & 1.9 & 34,822 \\
\hline 5 & 29 & 5.43 & 6.66 & 1981 & 40.48 & 48.30 & 4.27 & 45 & 1.4 & 41,172 \\
\hline 6 & 28 & 6.73 & 8.01 & 2076 & 42.63 & 50.68 & 5.39 & 36 & 1.2 & 38,312 \\
\hline 7 & 29 & 8.05 & 9.50 & 1980 & 77.36 & 16.56 & 5.35 & 26 & 1.0 & 44,984 \\
\hline 8 & 28 & 9.56 & 12.04 & 2216 & 70.40 & 18.77 & 5.49 & 32 & 1.0 & 39,224 \\
\hline 9 & 29 & 12.24 & 14.98 & 2233 & 80.83 & 9.44 & 4.54 & 23 & 1.0 & 52,422 \\
\hline 10 & 29 & 15.03 & 20.92 & 2040 & 71.46 & 16.07 & 9.22 & 17 & 1.0 & 47,679 \\
\hline TOTAL & 286 & & & & & & & & & \\
\hline
\end{tabular}

Figure 1 illustrates the findings listed in Table 2 by summarizing the $\mathrm{SPb}$ and $\mathrm{BPb}$ results and dividing them into 10 sectors by distance from the center of New Orleans (location of the Main Post Office or MPO). In 2000-2005, the median BPb at distances less than $6 \mathrm{~km}$ peaked at nearly $7 \mu \mathrm{g} / \mathrm{dL}$ and declined at distances $>6 \mathrm{~km}$ from MPO to $3 \mu \mathrm{g} / \mathrm{dL}$. For 2011-2016, the median BPb peaked at $3 \mu \mathrm{g} / \mathrm{dL}$ and declined to $1 \mu \mathrm{g} / \mathrm{dL}$ at $6 \mathrm{~km}$. Children's median BPb in New Orleans remains elevated closest to the center of the city and decreases with the distance from the MPO. These reductions are worthy of celebration, but there is no safe level of $\mathrm{BPb}$ in children [28]. 


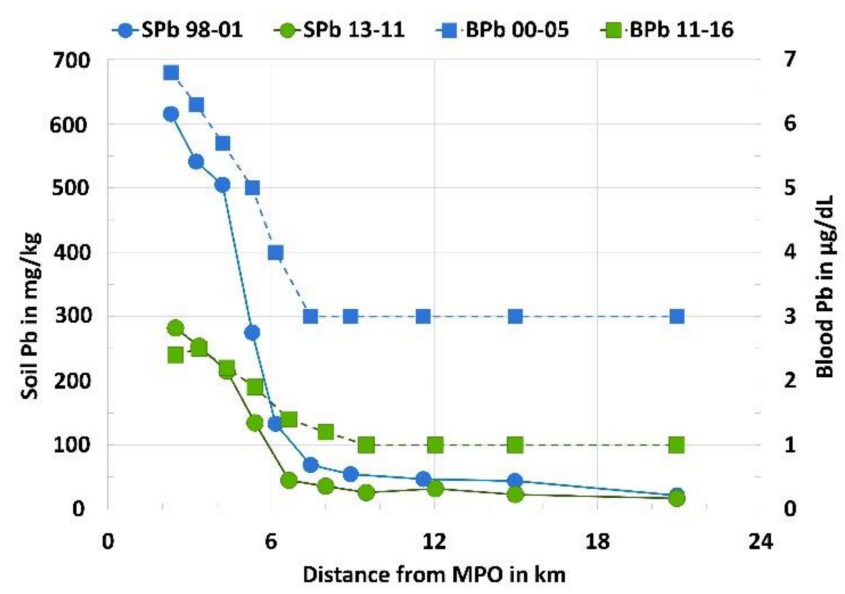

Figure 1. Soil $\mathrm{Pb}$ (circles with scale on the left) and blood $\mathrm{Pb}$ (squares with scale on the right) medians as a function of distance sectors from the Main Post Office (MPO) for the 1998-2001 soil $\mathrm{Pb}$ and 2000-2005 blood $\mathrm{Pb}$ surveys compared with the 2013-2017 soil Pb and 2011-2016 blood Pb surveys.

Figure 2 was derived from data in Table 2 and shows the decrease in children's median $\mathrm{BPb}$ by racial composition as a function of distance from the center of the city, where predominantly Black people live. The data display disproportionately high SPb in the NEAR vs. FAR groups of the city (Tables 1 and 2, and Figure 2), largely representing Black vs. White populations.

$2000-2005$

$2011-2016$
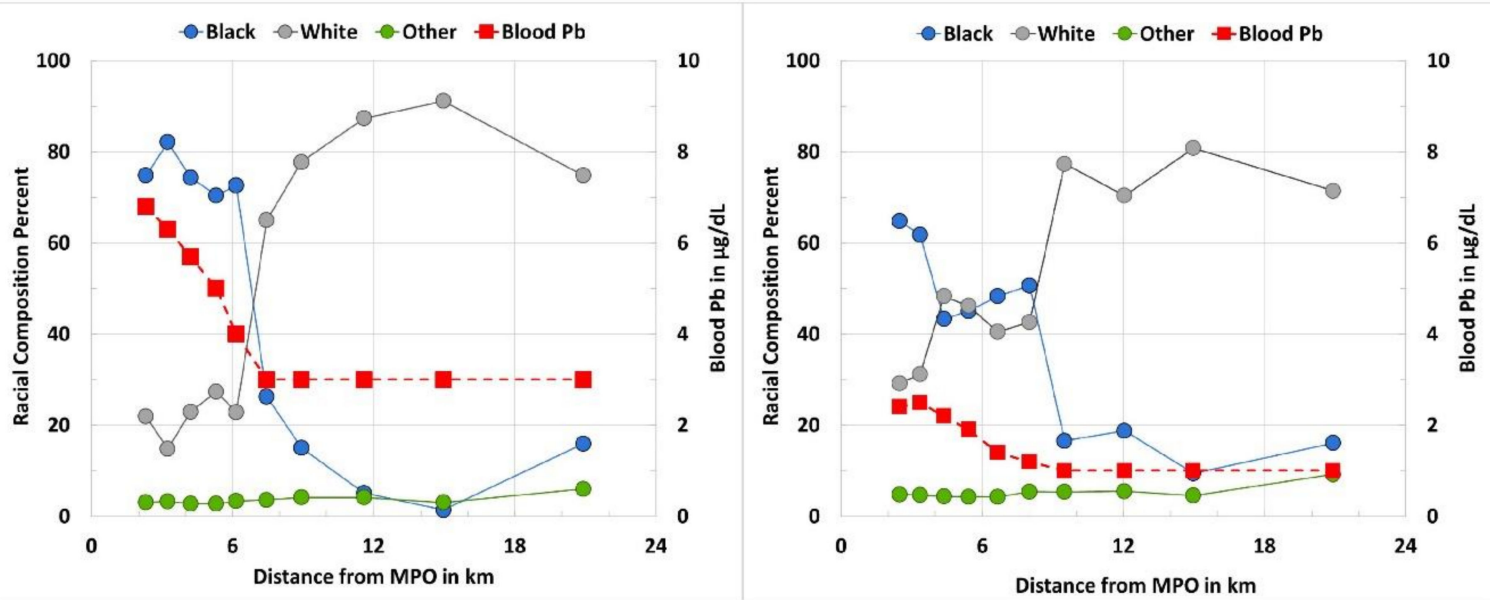

Figure 2. The relationship between racial composition and children's median blood $\mathrm{Pb}$ as a function of distance sectors from the Main Post Office (MPO) to outlying communities. Children's blood $\mathrm{Pb}(\mathrm{BPb})$ data (red squares with the scale on the right) are not disaggregated by race. The overall racial composition of the sampling areas are represented (blue, grey, and green circles with the scale on the left).

\section{Discussion}

4.1. Spatial-Temporal Distribution of Soil Pb and Blood Pb: Environmental Injustice for Black Populations

In the present study, metropolitan New Orleans is observed through spatial-temporal dimensions. As shown in Table 1, children's median BPb differences between NEAR and FAR groups in New Orleans are strongly associated with median $\mathrm{SPb}$ concentrations. This study notes that the predominantly Black populations living in the NEAR areas in 2000-2005 presented with a median BPb of $5.6 \mu \mathrm{g} / \mathrm{dL}$. The BPb of children living in NEAR 
communities have consistently been higher than children living in FAR communities. Children living in high SPb communities perpetuate patterns of environmental racism, disproportionately burdening low-income communities of color $[29,30]$.

Limited studies have documented the racial associations particular to $\mathrm{SPb}[14,31]$. However, similar geographic $\mathrm{SPb}$ patterns have been found elsewhere [11,12], and all major cities contain historical $\mathrm{Pb}$ emissions from gasoline [32]. The findings presented here are in concordance with the inequitable health outcomes of vulnerable populations, which have long been associated with racial segregation and poverty [33-35], including as a result of $\mathrm{Pb}$ exposure [5]. For example, in the National Health and Nutrition Examination Survey III, conducted from 1999 to 2004, non-Hispanic Black children were nearly three times more likely than White children to have $\mathrm{BPb}>10 \mathrm{ug} / \mathrm{dL}$ [36]. On the national scale, atmospheric $\mathrm{Pb}$ has been shown to positively correlate with percentages of Black children at the county level, while being inversely correlated to percentages of White youth [37]. The story of Flint, Michigan, has drawn attention to policies and practices that render Black, Brown and lowincome communities disproportionately vulnerable to toxicant exposure [38,39]. While $\mathrm{Pb}$ exposure from these other environmental media have been widely acknowledged, our data show that environmental $\mathrm{Pb}$, in the form of $\mathrm{SPb}$, should be recognized as contributing to the racial disparities of $\mathrm{BPb}$ exposure.

Measuring $\mathrm{SPb}$ provides insights into adverse racial and socio-economic effects from an invisible source of urban inequity. Soil $\mathrm{Pb}$ is likely contributing to racialized health inequities in many more cities than are currently recognized. Despite knowledge about $\mathrm{Pb}$ exposure in various forms, societal institutions have been "slow to recognize the racial ecology of lead poisoning as a major form of health inequality" [4]. Childhood $\mathrm{Pb}$ poisoning has been identified as a "signature disease of poverty" [40], as evidenced in Table 1, which may, in part, explain the inertia from governing bodies and legislative authorities to address $\mathrm{Pb}$ poisoning. The lack of attention paid to the issue of environmental $\mathrm{Pb}$ can also be attributed to federal policies and corporate interests that approved the commercial addition of $\mathrm{Pb}$ in various products, notably gasoline and paint, in the first place [41].

Concurrent decreases in $\mathrm{SPb}$ and $\mathrm{BPb}$ exist between the two survey periods [15]. These reductions in $\mathrm{BPb}$ and the overall use of $\mathrm{Pb}$ as a result of major policy changes are encouraging. However, as observed in Table 1 and Figure 2, SPb results remain high $(>190 \mathrm{mg} / \mathrm{kg}$ ) closest to the center of the city, where Black and lower-income residents predominantly live, and $\mathrm{SPb}$ is consistently lower $(<47 \mathrm{mg} / \mathrm{kg})$ where White and wealthier populations reside. Empirically, this study shows that only communities where $\mathrm{SPb}$ is less than $47 \mathrm{mg} / \mathrm{kg}$ have an adequate margin of safety to curtail excessive $\mathrm{Pb}$ exposure in children.

\subsection{Potential Implications for COVID-19}

As mentioned in the introduction, the health impacts of childhood $\mathrm{Pb}$ exposure may be lifelong, and worldwide $\mathrm{Pb}$ is a leading cause of mortality $[1,2,8]$. In the midst of the global coronavirus pandemic, we would be remiss not to call attention to the overlap between the outcomes of $\mathrm{Pb}$ exposure and the pre-existing conditions that have contributed to COVID-19 severity and mortality. While the data presented above document children's $\mathrm{BPb}$, there is increasing evidence suggesting that childhood $\mathrm{Pb}$ exposure is linked with adult health outcomes [42]. The first column of Table 3 lists the dominant pre-existing health conditions associated with severe COVID-19 symptoms [43]. Each of these preexisting conditions listed arises from $\mathrm{Pb}$ exposure, and relevant explanations and references are provided in the subsequent columns. Early reports in Italy demonstrated that $99 \%$ of those who died from COVID-19 had other illnesses, with 75\% having high blood pressure (hypertension), 35\% diabetes, and 33\% heart disease [44]. In an autopsy report of Black people who died as a result of COVID-19 in Louisiana, all had at least one comorbidity, the most common conditions being hypertension and type 2 diabetes [45]. As Table 3 shows, $\mathrm{Pb}$ exposure is associated with each of these conditions. While associations are not necessarily causative, they necessitate further investigation. 
Table 3. Pb exposure and COVID-19 comorbidity conditions.

\begin{tabular}{|c|c|c|}
\hline $\begin{array}{l}\text { Pre-Existing Condition for } \\
\text { COVID-19 Comorbidity }\end{array}$ & $\begin{array}{c}\text { Association with } \mathrm{Pb} \\
\text { Exposure }\end{array}$ & References \\
\hline $\begin{array}{l}\text { High blood pressure } \\
\text { (Hypertension) }\end{array}$ & $\begin{array}{c}\text { Most studied cardiovascular } \\
\text { outcome of } \mathrm{Pb} \text { exposure, } \\
\text { effects may occur at } \mathrm{BPb} \leq \\
5 \mu \mathrm{g} / \mathrm{dL} \text {. }\end{array}$ & $\begin{array}{l}\text { Apostoli et al., } 1990 \text { [46]; } \\
\text { Bertin de Almeida Lopes et al., } \\
2017 \text { [47] }\end{array}$ \\
\hline Coronary heart disease (CHD) & $\begin{array}{l}\text { A positive dose-response } \\
\text { relationship at } \mathrm{BPb} \leq \\
10 \mu \mathrm{g} / \mathrm{dL} \text { is an all-cause } \\
\text { mortality and mortality cause } \\
\text { of coronary heart disease. }\end{array}$ & $\begin{array}{l}\text { Menke et al., } 2006 \text { [48]; } \\
\text { Schober et al., } 2006 \text { [49] }\end{array}$ \\
\hline $\begin{array}{c}\text { Chronic obstructive } \\
\text { pulmonary disease (COPD) }\end{array}$ & $\begin{array}{c}\text { Over a BPb range of } \\
\leq 10 \mu \mathrm{g} / \mathrm{dL} \text { and } \mathrm{BPb}> \\
50 \mu \mathrm{g} / \mathrm{dL}, \text { workers had } \\
\text { decreased pulmonary } \\
\text { function, obstructive } \\
\text { pulmonary disease, increased } \\
\text { asthma, and shortness of } \\
\text { breath compared to controls. }\end{array}$ & $\begin{array}{l}\text { Chung et al., } 2015 \text { [50]; Pugh } \\
\text { Smith and Nriagu, } 2011 \text { [51] }\end{array}$ \\
\hline Chronic kidney disease (CKD) & $\begin{array}{c}\text { Exposure of } \mathrm{BPb}(\leq 10 \geq \\
50 \mu \mathrm{g} / \mathrm{dL}) \text { alters kidney } \\
\text { function and chronic kidney } \\
\text { disease }(\mathrm{CKD}) . \text { Renal } \\
\text { nephrotoxicity severity is } \\
\text { associated with } \\
\text { increasing } \mathrm{BPb} .\end{array}$ & $\begin{array}{l}\text { Muntner et al., } 2003 \text { [52]; } \\
\text { Pollack, } 2015 \text { [53] }\end{array}$ \\
\hline $\begin{array}{l}\text { Inflammation, immune } \\
\text { system disorders } \\
\text { and lymphatic system } \\
\text { dysfunction }\end{array}$ & $\begin{array}{l}\text { Elevated } \mathrm{BPb}(\geq 10 \mu \mathrm{g} / \mathrm{dL}) \text { is } \\
\text { an important factor in } \\
\text { autoimmune diseases, chronic } \\
\text { inflammation, and edema. }\end{array}$ & $\begin{array}{c}\text { Boskabady et al., } 2018 \text { [54]; } \\
\text { Mishra et al., } 2009 \text { [55]; CDC, } \\
1991 \text { [56]; Aghdam et al., } \\
\text { 2019 [57] }\end{array}$ \\
\hline
\end{tabular}

We call attention to these overlaps and question the extent to which people with morbidities from $\mathrm{Pb}$ exposure are more susceptible to becoming severely ill with COVID-19. Testing such a hypothesis would require measuring the bodily burden of $\mathrm{Pb}$, but such data were not available due to Health Insurance Portability and Accountability Act (HIPAA) restrictions. Even if such data were safely and anonymously available, $\mathrm{Pb}$ is stored in bone tissue and while noninvasive bone $\mathrm{Pb}$ analyses are available, they are not frequently performed. Hence, cumulative $\mathrm{Pb}$ impacts are commonly underrecognized [8]. Understanding the linkages between $\mathrm{Pb}$-associated morbidities and other adverse health issues such as COVID-19 would enable effective public health decisions to address and prevent exposure. Outside of general data on COVID-19, actual information on spatial-temporal infections with the new coronavirus, SARS-CoV-2, in the NEAR and FAR groups of New Orleans is lacking. Such data would also enable the verification of this hypothesis.

\subsection{Actions for Primary Prevention for Soil Pb}

The city-wide datasets for soil $\mathrm{Pb}$, blood $\mathrm{Pb}$, racial and socioeconomic factors, analyzed by distance from the city center and over time, indicate that disproportionate burdens of $\mathrm{Pb}$ exposure are placed on already vulnerable-and specifically Black and lowincome-populations in New Orleans. Action is needed to effectively prevent exposure to an invisible source of environmental $\mathrm{Pb}$ before health issues arise, and primary exposure prevention to $\mathrm{SPb}$ is surprisingly feasible. Contaminated soil can be affordably covered and, as long as the cover is maintained, primary prevention can be achieved [58]. The Norwegian parliament set a precedent in 2006 and established a national clean soil action program [59]. The New York City (NYC) Mayor's Office of Environmental Remediation 
established a Clean Soil Bank, which is the first municipal program in the U.S. to attempt such an endeavor [60]. The goals of the NYC program are to eliminate transporting clean excavation soil to landfills, save costs on soil imports, and enhance urban ecosystem services, as these soils mitigate $\mathrm{SPb}$ exposure. In so doing, the program may also address the systemic inequities that have been rendered undeniable by environmental justice organizing and research, as well as the data presented here. Lead is invisible and thus requires systematic mapping to understand the multiple ways in which exposure exacerbates urban environmental injustices. In particular, amidst the coronavirus pandemic, we call for further investigation into the adverse effects of $\mathrm{Pb}$ morbidity with severe COVID-19 outcomes. Soil lead cleanup should be considered, along with other measures, as a path forward to address an urgent and racially unjust environmental factor-one that will not only promote overall health but may also mitigate current and future pandemics.

Supplementary Materials: The following are available online at https://www.mdpi.com/1660-4 601/18/3/1314/s1, Table S1: Kendall's tau-b correlation results and $p$-values. The potential for $\mathrm{Pb}$ exposure and comorbidity is highest among people living within the inner city of New Orleans; Table S2: The data file for the study.

Author Contributions: C.R.G. organized and analyzed the data for Tables 1 and 2 and Figures 1 and 2; E.T.P. performed field collections and, with C.R.G., conducted the final laboratory analyses; S.P.E. and J.A.C.-G. Developed Table 2; S.P.E., C.R.G. and H.W.M. wrote the manuscript; H.W.M. oversaw the project. All authors have read and agreed to the published version of the manuscript.

Funding: Agency for Toxic Substances and Disease Registry (ATSDR) and Housing and Urban Development (HUD) provided initial funding and further support was provided by The Ling and Ronald Cheng Fund, Al French, Mary An Godshall, Allen and Laura Carmen, and the Tulane Department of Pharmacology.

Institutional Review Board Statement: Individual children's blood $\mathrm{Pb}$ results are unidentifiable and no formal IRB review was required.

Informed Consent Statement: The Children's blood Pb datasets were obtained from the Louisiana Healthy Homes and Childhood Lead Poisoning Prevention Program (LHHCLPPP). The program follows CDC guidelines and protocols.

Data Availability Statement: The complete dataset for this study is available from the IJERPH website at www.mdpi.com/xxx/s1.

Acknowledgments: The authors thank John A. McLachlan, Tulane Department of Pharmacology, for his encouragement after reading an early draft. Kenneth Berry and Janis Johnson provided guidance with the statistical analyses. This manuscript is dedicated to the memory of Paul W. Mielke Jr., developer of MRPP statistics and Mielke's R.

Conflicts of Interest: H.W.M. is the unremunerated president of Lead Lab, Inc. The other co-authors report that they have no conflicts of interest.

\section{References}

1. Stanaway, J.D.; Afshin, A.; Gakidou, E.; Lim, S.S.; Abate, D.; Abate, K.H.; Abbafati, C.; Abbasi, N.; Abbastabar, H.; Abd-Allah, F.; et al. Global, Regional, and National Comparative Risk Assessment of 84 Behavioural, Environmental and Occupational, and Metabolic Risks or Clusters of Risks for 195 Countries and Territories, 1990-2017: A Systematic Analysis for the Global Burden of Disease Study 2017. Lancet 2018, 392, 1923-1994. [CrossRef]

2. Lanphear, B.P.; Rauch, S.; Auinger, P.; Allen, R.W.; Hornung, R.W. Low-Level Lead Exposure and Mortality in US Adults: A Population-Based Cohort Study. Lancet Public Health 2018, 3, e177-e184. [CrossRef]

3. O'Connor, D.; Hou, D.; Ok, Y.S.; Lanphear, B.P. The Effects of Iniquitous Lead Exposure on Health. Nat. Sustain. 2020, 3, 77-79. [CrossRef]

4. Sampson, R.J; Winter, A.S. The Racial Ecology of Lead Poisoning: Toxic Inequality in Chicago Neighborhoods, 1995-2013. Du Bois Rev. Soc. Sci. Res. Race 2016, 13, 261-283. [CrossRef]

5. Lanphear, B.P.; Weitzman, M.; Eberly, S. Racial Differences in Urban Children's Environmental Exposures to Lead. Am. J. Public Health 1996, 86, 1460-1463. [CrossRef]

6. Leech, T.G.J.; Adams, E.A.; Weathers, T.D.; Staten, L.K.; Filippelli, G.M. Inequitable Chronic Lead Exposure: A Dual Legacy of Social and Environmental Injustice. Fam. Community Health 2016, 39, 151. [CrossRef] 
7. Whitehead, L.S.; Buchanan, S.D. Childhood Lead Poisoning: A Perpetual Environmental Justice Issue? J. Public Health Manag. Pract. 2019, 25, S115. [CrossRef]

8. Abadin, H.; Ashizawa, A.; Llados, F.; Stevens, Y.W. Toxicological Profile for Lead; U.S. Department of Health and Human Services, Public Health Service: Atlanta, GA, USA, 2020; p. 583.

9. Parsons, P.J.; McIntosh, K.G. Human Exposure to Lead and New Evidence of Adverse Health Effects: Implications for Analytical Measurements. Powder Diffr. 2010, 25, 175-181. [CrossRef]

10. Centers for Disease Control and Prevention CDC—Lead-Blood Lead Levels in Children. Available online: https:/ /www.cdc. gov/nceh/lead/prevention/blood-lead-levels.htm (accessed on 14 September 2019).

11. Mielke, H.W.; Anderson, J.C.; Berry, K.J.; Mielke, P.W.; Chaney, R.L.; Leech, M. Lead Concentrations in Inner-City Soils As a Factor in the Child Lead Problem. Am. J. Public Health 1983, 73, 1366. [CrossRef]

12. Mielke, H.W. Lead Dust Contaminated U.S.A. Communities: Comparison of Louisiana and Minnesota. Appl. Geochem. 1993, 8, 257-261. [CrossRef]

13. Lark, R.M.; Scheib, C. Land Use and Lead Content in the Soils of London. Geoderma 2013, 209-210, 65-74. [CrossRef]

14. Masri, S.; LeBrón, A.; Logue, M.; Valencia, E.; Ruiz, A.; Reyes, A.; Lawrence, J.M.; Wu, J. Social and Spatial Distribution of Soil Lead Concentrations in the City of Santa Ana, California: Implications for Health Inequities. Sci. Total Environ. 2020, 743, 140764. [CrossRef] [PubMed]

15. Mielke, H.W.; Gonzales, C.R.; Powell, E.T.; Laidlaw, M.A.S.; Berry, K.J.; Mielke, P.W.; Egendorf, S.P. The Concurrent Decline of Soil Lead and Children's Blood Lead in New Orleans. PNAS 2019, 116, 22058-22064. [CrossRef] [PubMed]

16. NHGIS, N.H.G.I.S. Census Tract Boundary Files. Year 2000 and 2010 TIGER/Line Features for Jefferson, Orleans, and St. Bernard Parishes in Louisiana, USA; US Census Bureau: Sutherland, MD, USA, 2020.

17. Mielke, H.W.; Gonzales, C.; Powell, E.; Mielke, P.W. Changes of Multiple Metal Accumulation (MMA) in New Orleans Soil: Preliminary Evaluation of Differences between Survey I (1992) and Survey II (2000). Int. J. Environ. Res. Public Health 2005, 2, 308-313. [CrossRef] [PubMed]

18. Jenness, J. Center of Mass (Center_of_mass.Avx) Extension for ArcView 3.x.; Jenness Enterprises: Flagstaff, AZ, USA, 2006.

19. Golden Software LLC. Surfer $17^{\circledR} 17.1 .288$ (64-bit) Dec 11 2019. Golden Software LLC: 809 14th Street, Golden, CO, USA. Available online: www.goldensoftware.com (accessed on 30 June 2020).

20. ESRI. ArcGIS Desktop 10; Environmental Systems Research Institute: Redlands, CA, USA, 2011.

21. Reich, A.A. Transportation Efficiency. Strateg. Plan. Energy Environ. 2012, 32, 32-43. [CrossRef]

22. Manson, S.; Schroeder, J.; Van Riper, D.; Ruggles, S. Integrated Public Use Microdata Series (IPUMS) National Historical Geographic Information System: Version 14.0 [Database]; IPUMS: Minneapolis, MN, USA, 2019.

23. Cade, B.S.; Richard, J. User Manual for Blossom Statistical Software; U.S. Geological Survey: Reston, VA, USA, 2001 ; p. 128.

24. Berry, K.J.; Johnston, J.E.; Mielke, P.W. A Chronicle of Permutation Statistical Methods: 1920-2000, and Beyond; Springer International Publishing: Cham, Switzerland, 2014; ISBN 978-3-319-02743-2.

25. Mielke, P.W., Jr.; Berry, K.J. Permutation Methods: A Distance Function Approach. In Springer Series in Statistics, 2nd ed.; Springer: New York, NY, USA, 2007; ISBN 978-0-387-69811-3.

26. Berry, K.J.; Mielke, P.W. A Generalization of Cohen's Kappa Agreement Measure to Interval Measurement and Multiple Raters. Educ. Psychol. Meas. 1988, 48, 921-933. [CrossRef]

27. IBM Corp. IBM SPSS Statistics for Macintosh; IBM Corporation: Armonk, NY, USA, 2015.

28. CDC. Centers for Disease Control and Prevention (CDC) Response to Advisory Committee on Childhood Lead Poisoning Prevention Recommendations in "Low Level Lead Exposure Harms Children: A Renewed Call of Primary Prevention". Department of Health and Human Services, CDC; 2012. Available online: http://www.cdc.gov/nceh/lead/acclpp/cdc_response_lead_ exposure_recs.pdf (accessed on 30 June 2020).

29. Bullard, R.D. Confronting Environmental Racism: Voices from the Grassroots; South End Press: Boston, MA, USA, 1993; ISBN 978-0-89608-446-9.

30. Campanella, R.; Mielke, H.W. Human Geography of New Orleans' High-Lead Geochemical Setting. Environ. Geochem. Health 2008, 30, 531-540. [CrossRef]

31. McClintock, N. A Critical Physical Geography of Urban Soil Contamination. Geoforum 2015, 65, 69-85. [CrossRef]

32. Mielke, H.W.; Laidlaw, M.A.S.; Gonzales, C.R. Estimation of Leaded (Pb) Gasoline's Continuing Material and Health Impacts on 90 US Urbanized Areas. Environ. Int. 2011, 37, 248-257. [CrossRef]

33. Pellow, D. Garbage Wars: The Struggle for Environmental Justice in Chicago; MIT Press: Cambridge, MA, USA, 2002; ISBN 978-0-26266187-4.

34. Massey, D.S. Segregation and Stratification: A Biosocial Perspective. Du Bois Rev. 2004, 1, 7-25. [CrossRef]

35. Morello-Frosch, R.; Lopez, R. The Riskscape and the Color Line: Examining the Role of Segregation in Environmental Health Disparities. Environ. Res. 2006, 102, 181-196. [CrossRef] [PubMed]

36. Jones, R.L.; Homa, D.M.; Meyer, P.A.; Brody, D.J.; Caldwell, K.L.; Pirkle, J.L.; Brown, M.J. Trends in Blood Lead Levels and Blood Lead Testing Among US Children Aged 1 to 5 Years, 1988-2004. Pediatrics 2009, 123, e376-e385. [CrossRef] [PubMed]

37. Stretesky, P.B. The Distribution of Air Lead Levels across U.S. Counties: Implications for the Production of Racial Inequality. Sociol. Spectr. 2003, 23, 91-118. [CrossRef] 
38. Laidlaw, M.A.S.; Filippelli, G.M.; Sadler, R.C.; Gonzales, C.R.; Ball, A.S.; Mielke, H.W. Children's Blood Lead Seasonality in Flint, Michigan (USA), and Soil-Sourced Lead Hazard Risks. Int. J. Environ. Res. Public Health 2016, 13, 358. [CrossRef]

39. Pulido, L. Flint, Environmental Racism, and Racial Capitalism. Capital. Nat. Soc. 2016, 27, 1-16. [CrossRef]

40. Markowitz, G.; Rosner, D. Lead Wars: The Politics of Science and the Fate of America's Children; University of California Press: Berkeley, CA, USA, 2013.

41. Benfer, E.A. Contaminated Childhood: How The United States Failed to Prevent the Chronic Lead Poisoning of Low-Income Children and Communities of Color. Harv. Environ. Law Rev. 2017, 41, 70.

42. Bellinger, D.C. Childhood Lead Exposure and Adult Outcomes. JAMA 2017, 317, 1219-1220. [CrossRef]

43. Guan, W.; Liang, W.; Zhao, Y.; Liang, H.; Chen, Z.; Li, Y.; Liu, X.; Chen, R.; Tang, C.; Wang, T.; et al. Comorbidity and Its Impact on 1590 Patients with COVID-19 in China: A Nationwide Analysis. Eur. Respir. J. 2020, 55. [CrossRef]

44. Ebhardt, T.; Remondini, C.; Bertacche, M. 99\% of Those Who Died From Virus Had Other Illness, Italy Says. 18 March 2020. Available online: https://thebridgelifeinthemix.info/wp-content/uploads/2020/04/SB-7.-www_bloomberg_com_news_ articles_2020_03_18_99_of_those_who_d.pdf (accessed on 30 June 2020).

45. Fox, S.E.; Akmatbekov, A.; Harbert, J.L.; Li, G.; Quincy Brown, J.; Vander Heide, R.S. Pulmonary and Cardiac Pathology in African American Patients with COVID-19: An Autopsy Series from New Orleans. Lancet Respir. Med. 2020, 8, 681-686. [CrossRef]

46. Apostoli, P.; Maranelli, G.; Dei Cas, L.; Micciolo, R. Blood Lead and Blood Pressure: A Cross Sectional Study in a General Population Group. Cardiologia 1990, 35, 597-603.

47. De Almeida Lopes, A.C.B.; Silbergeld, E.K.; Navas-Acien, A.; Zamoiski, R.; da Cunha Martins, A., Jr.; Camargo, A.E.I.; Urbano, M.R.; Mesas, A.E.; Paoliello, M.M.B. Association between Blood Lead and Blood Pressure: A Population-Based Study in Brazilian Adults. Environ. Health 2017, 16, 27. [CrossRef] [PubMed]

48. Menke, A.; Muntner, P.; Batuman, V.; Silbergeld, E.K.; Guallar, E. Blood Lead Below 0.48 Mmol/L (10 Mg/DL) and Mortality Among US Adults. Circulation 2006, 114, 1388-1394. [CrossRef] [PubMed]

49. Schober, S.E.; Mirel Lisa, B.; Graubard Barry, I.; Brody Debra, J.; Flegal Katherine, M. Blood Lead Levels and Death from All Causes, Cardiovascular Disease, and Cancer: Results from the NHANES III Mortality Study. Environ. Health Perspect. 2006, 114, 1538-1541. [CrossRef] [PubMed]

50. Chung, H.K.; Chang, Y.S.; Ahn, C.W. Effects of Blood Lead Levels on Airflow Limitations in Korean Adults: Findings from the 5th KNHNES 2011. Environ. Res. 2015, 136, 274-279. [CrossRef] [PubMed]

51. Pugh Smith, P.; Nriagu, J.O. Lead Poisoning and Asthma among Low-Income and African American Children in Saginaw, Michigan. Environ. Res. 2011, 111, 81-86. [CrossRef] [PubMed]

52. Muntner, P.; He, J.; Vupputuri, S.; Coresh, J.; Batuman, V. Blood Lead and Chronic Kidney Disease in the General United States Population: Results from NHANES III. Kidney Int. 2003, 63, 1044-1050. [CrossRef] [PubMed]

53. Pollack, A.Z.; Mumford, S.L.; Mendola, P.; Perkins, N.J.; Rotman, Y.; Wactawski-Wende, J.; Schisterman, E.F. Kidney Biomarkers Associated with Blood Lead, Mercury, and Cadmium in Premenopausal Women: A Prospective Cohort Study. J. Toxicol. Environ. Health Part A 2015, 78, 119-131. [CrossRef] [PubMed]

54. Boskabady, M.; Marefati, N.; Farkhondeh, T.; Shakeri, F.; Farshbaf, A.; Boskabady, M.H. The Effect of Environmental Lead Exposure on Human Health and the Contribution of Inflammatory Mechanisms, a Review. Environ. Int. 2018, 120, 404-420. [CrossRef]

55. Mishra, K.P. Lead Exposure and Its Impact on Immune System: A Review. Toxicol. In Vitro 2009, 23, 969-972. [CrossRef]

56. Roper, W.L.; Houk, V.N.; Falk, H.; Binder, S. Preventing Lead Poisoning in Young Children: A Statement by the Centers for Disease Control, October 1991; Centers for Disease Control: Atlanta, GA, USA, 1991.

57. Aghdam, K.A.; Zand, A.; Sanjari, M.S. Bilateral Optic Disc Edema in a Patient with Lead Poisoning. J. Ophthalmic Vis. Res. 2019, 14, 513-517. [CrossRef]

58. Laidlaw, M.A.S.; Filippelli, G.M.; Brown, S.; Paz-Ferreiro, J.; Reichman, S.M.; Netherway, P.; Truskewycz, A.; Ball, A.S.; Mielke, H.W. Case Studies and Evidence-Based Approaches to Addressing Urban Soil Lead Contamination. Appl. Geochem. 2017, 83, 14-30. [CrossRef]

59. Ottesen, R.T.; Alexander, J.; Langedal, M.; Haugland, T.; Høygaard, E. Soil Pollution in Day-Care Centers and Playgrounds in Norway: National Action Plan for Mapping and Remediation. Environ. Geochem. Health 2008, 30, 623-637. [CrossRef] [PubMed]

60. Egendorf, S.P.; Cheng, Z.; Deeb, M.; Flores, V.; Paltseva, A.; Walsh, D.; Groffman, P.; Mielke, H.W. Constructed Soils for Mitigating Lead $(\mathrm{Pb})$ Exposure and Promoting Urban Community Gardening: The New York City Clean Soil Bank Pilot Study. Landsc. Urban Plan. 2018, 175, 184-194. [CrossRef] 